\title{
Hidden Valley Sanctuary
}

By R. C. Mackenzie

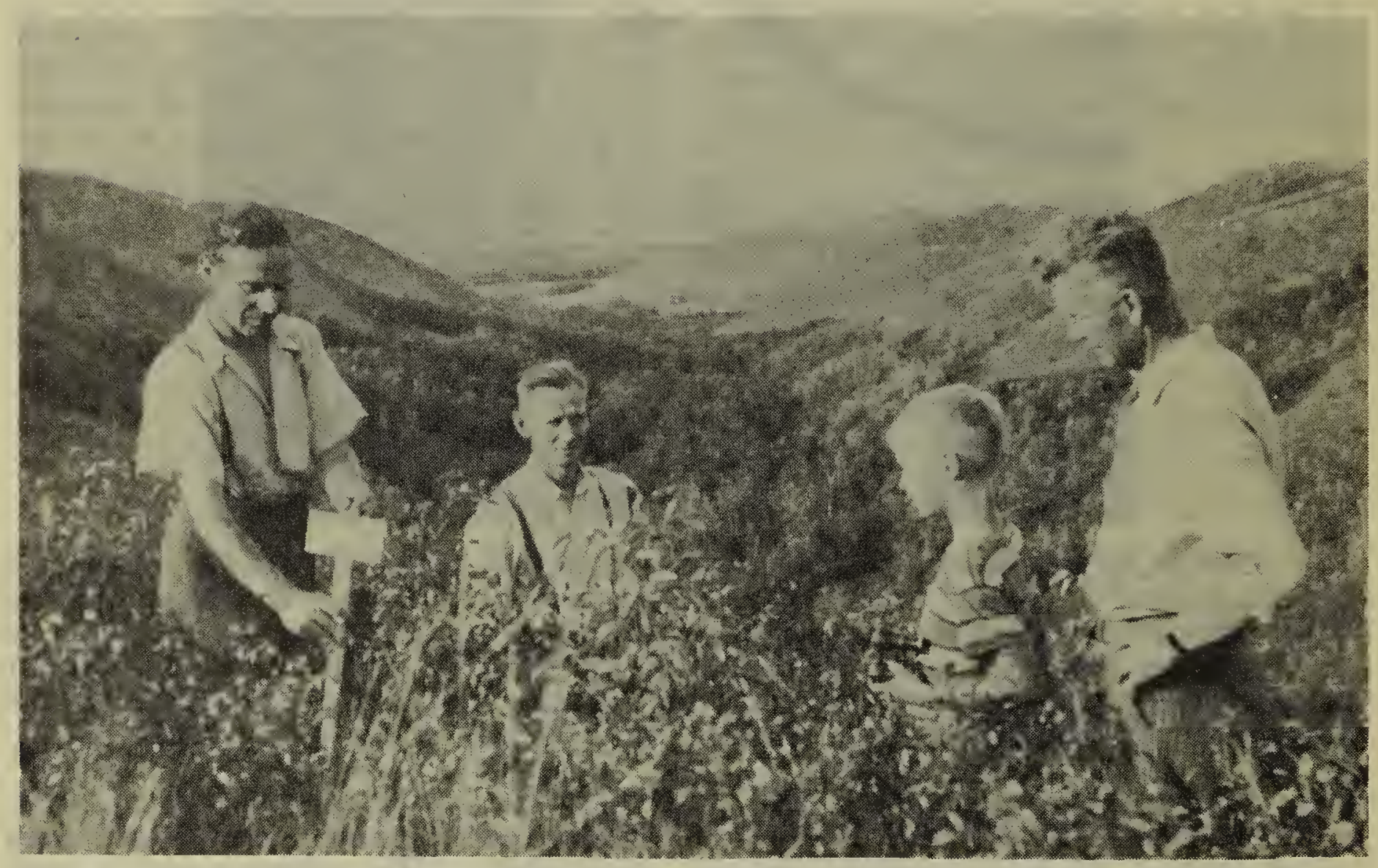

Bob Mackenzie, Lloyd Carmichael, Dr. Jake Remple and Son labelling the Nature Trail in Hidden Valley.

$\mathbf{T}^{\mathrm{T}}$ HE Regina Natural History Society maintains a wild life sanctuary in the Qu'Appelle Valley, about twentysix miles north-west of Regina city. It comprises a half section of land and includes a long narrow valley, tributary to the main valley of the Qu'Appelle River, and all or part of five connecting coulees.

It is a surprising place of steep bare hills and deep narrow ravines, these last being overgrown to about onethird of the height of encompassing hills with thick woods and tangled underbrush. The high ridges of the hills are fully three hundred feet above the valley bottoms, and windswept, boulder studded grassy uplands offer contrast to the shady woods and thick undergrowth of the deep coulees.

Through woods of Poplar, Elm, Ash, and Manitoba Maple, with underbrush of Chokecherry, Saskatoon bush, Willow and Dogwood, narrow winding deer trails lead into mysterious depths of hidden coulees. These are sanctuary and home to almost every variety of bird found in the central prairie region, including such comparatively rare birds as Scarlet Tanagers, Baltimore Orioles, and both Eastern and Mountain Bluebirds. White-tailed deer live there, as do porcupines, badgers, and weasels. There are red squirrels, ground squirrels and chipmunks aplenty, and a multitude of rabbits. 
Nor are the predators absent where the larder is so well filled, the Great Horned Owls nest there, as do many of their smaller cousins; there are hawks, magpies, crows, and the wily coyote.

In this wild place, hills and coulees remain much as they have always been through immemoriable ages. When Hind explored the Qu'Appelle Valley and camped nearby at the edge of the river flats, in the early summer of 1858 , the hidden coulees were much as they are today. Long before his ti:ne, Cree and Assiniboine buffalo hunters camped in the wooded bottomlands hereabout, or set up their teepees on windy hilltops where they could watch for buffalo on the high southward plains, and on the grassy river flats below. The bones of buffalo are there yet, showing in washout in the gullies and in the dry beds of spring-creeks in the ravines. Though the hunters have long since gone, stone teepee rings still mark the sites of ancient camps, and sometimes on the wind eroded ridges of the hills a flint scraper or arrow head will be found, silent witness of the long ago. During the many long years the steep hills have guarded the valleys well, and beast and bird, flower and trees, have remained unseen and undisturbed by man.

Since the Regina Natural History Society took the place over and posted its boundaries, wild life in these coulees has remained fairly secure. Hunting is no longer allowed, trees are not cut down, and wild flowers grow unpicked to bloom and multiply.

A narrow trail, passable to a car, winds and twists as it ascends through dense woods of maple, elm and poplar $_{r}$ to the small secluded nook cleared for a campsite. This is in a deep ravine, and hills rise in sheer heights above. There is about an acre of almost flat land at this spot with the dry bed of a spring-creek meandering across it, the whole area shaded by Black Poplar, Elm and Aspen woods. A group of Regina naturalists cleared this area several years ago, and cut out the narrow trail that leads back down the coulee to the valley road. We, at that time, for I was one of them, by trenching into the hillside and building with stone, constructed a small open-air fireplace, with chimney and iron cooking grill, and nearby seats made from logs. A few of us camp there every year, and sometimes a picnic is held in this place. Most of the time the silent coulees of Hidden Valley are left to the creatures whose home it is. We are intruders in these ravines, friendly though we are to all wild things, for this is a place belonging to the wilderness and our effort has been to keep it so.

Often when I have kindled a fire in the fireplace at Campsite, Ground Squirrels have watched me from the top of a nearby brush pile, a Chipmunk chattered loudly in a tree above, and Crows and Magpies flying low have nosily voiced their disapproval. Through a gap in the leafy dome above I have seen a Redtail Hawk circling high in the blue and watching my intrusion with deep suspicion.

Hidden Valley is a good place to spend a day in June or July and to stay until the late hour that darkness falls in midsummer. Deer can almost always be seen there, Meadow Larks sing joyfully on warm mornings, the cooing of Wood Pigeons often fill the woods in the late afternoons. Passing through a willow thicket one might come upon a Bush Partridge with young, the old bird flying almost into your face to draw attention away (Continued on Page 27) 


\section{HIDDEN VALLEY SANCTUARY}

(Continued from Page 17)

from her babies, the young ones scattering out of sight in the thick bush. A glimpse can often be caught of the high-jumping White-tail Deer, sometimes a fine buck with horns still in velvet, sometimes a doe with a beautiful little spotted fawn, might cross the path ahead of you.

Saskatoon berries, in season, grow in abundance. There are sweet wild strawberries besides the trails, and raspberries in the thickets and as darkness falls owls call whur-who-oo and rabbits stir in the sheltering dusk of tangled chokecherry thickets.

On the high hills in spring, tiny Mossphlox and Townsendia bloom, and later come the brilliant wax-like flowers of the Prickly Pear and Purple Ball Cactus. June brings many thousands of Roses, Wood Anemone and Shooting Star. Western Red Lilies can be found in the coulees in summer, and in the autumn of the year, come Bergamot, Asters and Goldenrod.

It might be a good thing if such sanctuaries for wild creatures, for trees, and for wild flowers, were established in many parts of our province. Perhaps in your own district there is a valley, slough or stretch of lakeshore, that could be preserved in its natural state for the enjoyment of all of those who are interested in the beauties of nature.

\section{CONSERVATION IN PRACTISE}

(Continued from Page 21)

goslings. This fall the goslings will be allowed to migrate. It is hoped that they will return again, if even for a brief stay.

This worthy project is a striking example of conservation in action. The Canada Goose has sadly diminished in numbers over much of its common territory in Saskatchewan through expanded farming observations and marsh draining projects. There seems no good reason that many others could not start similar conservation projects. All that is required is enthusiasm, a pair of geese and full co-operation of all who live near or visit the protected areas.

\section{THE SAW-LOC BIRD-BOX}

CAN BE MADE IN SUITABLE SIZES FOR TPEE SWALLOWS, BLUEBIPDS, WPENS AND CHICKADEES-
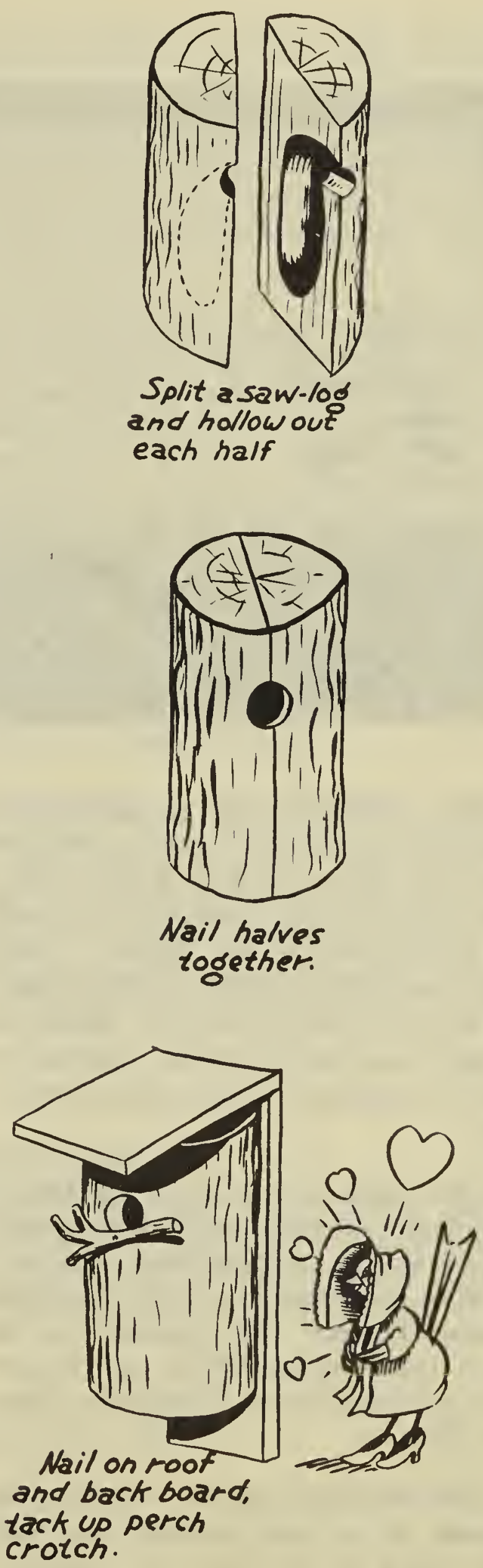